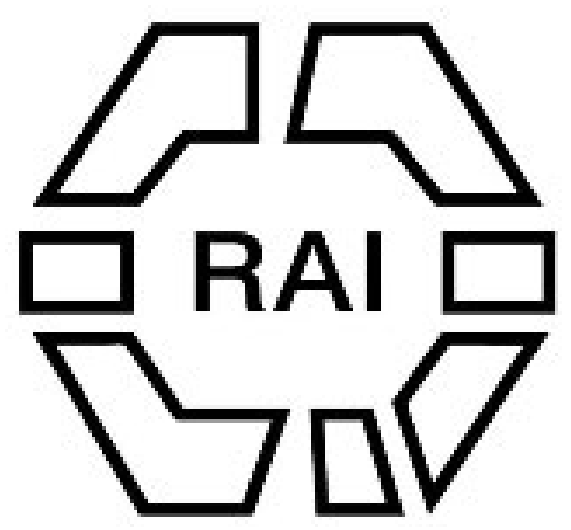

On the Earliest Communications Between Italy and Scandinavia Author(s): Oscar Montelius

Source: The Journal of the Anthropological Institute of Great Britain and Ireland, Vol. 30 (1900), pp. 89-94

Published by: Royal Anthropological Institute of Great Britain and Ireland

Stable URL: http://www.jstor.org/stable/2842621

Accessed: 14/06/2014 01:45

Your use of the JSTOR archive indicates your acceptance of the Terms \& Conditions of Use, available at http://www.jstor.org/page/info/about/policies/terms.jsp

JSTOR is a not-for-profit service that helps scholars, researchers, and students discover, use, and build upon a wide range of content in a trusted digital archive. We use information technology and tools to increase productivity and facilitate new forms of scholarship. For more information about JSTOR, please contact support@jstor.org. 


\section{ON THE EARLIEST COMMUNICATIONS BETWEEN ITALY AND SCANDINAVIA.}

\section{By Professur Oscar Montelius.}

[Presented May 29th, 1900. With Plates V, VI, ViI, Vili.]

THE commerce between Northern Europe and more southern countries goes very far back. During the first centuries after Christ, the Roman Empire extended over a great part of Central Europe, and the distance from the Roman territory in Germany to South Scandinavia was not a great one. In fact many Roman objects dating from those centuries have been met with in Sweden and in the other Scandinavian countries. But there have also been found in Scandinavia a great number of things belonging to the time before Christ, which can be show to have been brought from Italy and Central Europe.

Bronze vessels like Figs. 1-4 date from the last centuries B.c. Many vessels of these types are known from Sweden, Denmark, and Northern Germany. They were all fabricated in Italy or other parts of Southern Europe.

From the middle of the last millennium B.c. date such ciste a corcloni as Fig. 9. The original of this figure was found near Lubeck; many similar ciste have been met with in Northern Germany, in Hanover as well as in Posen. To about the same time belongs the situla Fig. 8, found in Denmark. Other situle of the same type are known from Northern Germany. The ciste a cordoni as well as the situle were imported from the South, and many vessels exactly of the same types have been found in Southern Germany, in Austria, and Italy.

Earlier than the ciste and situle just mentioned are such bronze vessels as Fig. 10 ; and still earlier, those like Fig. 6 . Five buckets of the same type as Fig. 10 are known from Northern Europe: one from Brandenburg, one from the northern part of the province of Saxe, two from Denmark, and the fifth from Sweden. It is very remarkable, that all these five foreign vessels were deposited with northern bronzes of the 5th period of the Scandinavian and North German Bronze age. Buckets of the same type occur in Southern Europe: one was found in Austria and another in Northern Italy, in one of the pre-Etruscan tombs at Bologna. Several vessels like Fig. 6 have been discovered in Denmark and Northern Germany, and other vessels exactly of the same type are known from more southern parts of Europe.

Personal ornaments of thin bronze with decorations of repoussé work in simple patterns, Fig. 7, belong to the same.time as the buckets like Fig. 10. Such 
ornaments are not rare in Sweden, Denmark, and Northern Germany ; and they too have all been imported from Southern or Central Europe.

To the beginning of the last millennium B.c. belong such swords as Figs. 11 and 15, with blade and hilt of bronze. Some swords like Fig. 15 have ornaments of iron inlaid on the hilt. Their blades, however, are of bronze, and the inlaid ornaments of iron prove that they date from a period when iron had only just begun to be known. The new metal was so rare that it could only be used for decoration; the weapon itself was of the old material, bronze.

Many swords of these two types (Figs. 11 and 15) have been found in Denmark and Sweden. The original of Fig. 15 was discovered, some years ago, in the south-western part of Finland, opposite the Sivedish coast. Exactly similar swords are common in Central Europe and Italy, and were evidently fabricated there. That swords like Fig. 15 were cast in Central Europe cannot be doubted, for a bronze mould for such a hilt (Fig. 14) has been found in Bavaria.

I mention also objects which were made in Central Europe, because their presence in Scandinavia tells us that about and before the time of the foundation of Rome there really was commerce between Northern and Central Europe; just as, on the other hand, the great number of Italian objects of the same period found in the Central European countries shows us how important the trade between those countries and Italy already was.

The bronze shields, Figs. 12 and 13, are nearly contemporaneous with the swords mentioned just now. One of these shields was found in Sweden, the other in Denmark, and similar bronze shields are known from Denmark and Germany. All of them were discovered in peat-bogs, and their wonderful state of preservation is due to the peat.

Similar repoussé ormaments to those in Fig. 12, which consist of wheels and pairs of snakes, and are imitations of the common Egyptian representation of the sun's disc and the two uræus snakes, are to be seen also on other bronze vessels (Figs. 16 and 18) dating from the very beginning of the last millennium B.c.

Two big vases like Fig. 16 were taken out from a peat-bog in Denmark; and two quite similar ones from a peat-bog in Mecklenburg. Two similar vases are known from Central Europe, one of these discovered in Bavaria and the other in Hungary. And a vase of the same form and with the same ornaments was found in Northern Italy.

The original of Fig. 18 was found in a Swedish peat-bog. An exactly similar vase, containing eleven gold-cups, stood in a Danish peat-bog. Similar vases have also been found in Denmark, Northern Germany, and Bohemia. Now, as several bronze vases of the same shape and with just the same decoration appear also in Italy, there can be no doubt that all these vases are of Italian origin. They occur bọth in Northern and Central Italy.

Of the same period as the big vases (Figs. 16 and 18) date such bronze-cups as Fig. 20, and many of them are found in Southern Scandinavia, Northern Germany, Central Europe and Italy. 
A little earlier are bronze cups of the type Fig. 19. They, too, were imported into Scandinavia and Northern Germany from Italy or from some part of Central Europe, where the Italian influence was very strong.

To about the same time as the last mentioned bronze cups belong the small bronze chariots supporting bronze vases (Fig. 5), which have been discovered in Sweden, Denmark, Northern Germany, and Bohemia. They also are imported from the South.

From a more remote period, the middle of the second millennium B.c., there are a great many highly interesting proofs of the intercourse between Scandinavia and Southern Europe. The Baltic amber appears in Greece at least 1500 years B.C., for several hundred beads from Mycenrean tombs have been shown by chemical analysis to be of Baltic amber. On the other hand the influence of Southern Europe on Scandinavia was at the same time so strong that bronze fibulæ (Fig. 17) and spiral ornaments of southern origin were common in our countries.

We can trace the same influence back not only to the beginning of the second millennium--Italian bronze daggers (Fig. 21) are found in Northern Germany; bronze daggers imitating them and bronze axes ("celts") of Italian form are common in Germany and Scandinavia-but even to the third millennium B.C., as I just have proved in a paper, printed in Germany. ${ }^{1}$

It is a most remarkable fact, that all those bronze vessels and other objects coming from Italy are so common in the western part of present-day Austria, in Germany-especially in the more eastern parts-and in Scandinavia, but are so extremely rare in Western Europe. No such kronze vessels as Figs. 5, 6, 8-10, 16, 18-20 have been met with in France, Great Britain, or Ireland.

We can trace the route followed by the commerce that imported those objects into North Germany and Scandinavia. It was the same route as that which was followed by the amber trade from Denmark and North Germany to Southern Europe.

The time that was indispensable for carrying the Italian articles to Scandinavia was not long. We know that in the last century B.c. the tin came from the English Channel to Marseilles in about thirty days, so that two months would be sufficient to bring the bronzes from Northern Italy to the coast of the Baltic. And if we do not consider two months sufficient, we must at all events admit that six months or a year, or at least two years, would he enough. And if so, we are fully entitled to say that the Italian bronzes imported to Scandinavia were in use contemporaneously in Sweden and in Italy.

\section{DISCUSSION.}

The President: I need say nothing about the interesting character of the very remarkable lecture, as that is obvious to all of us; but I think this lecture has

1 Montelius, Die, Chronologie der ältesten Bronzezeit in Nord-Deutschland und Skandinaveen (Braunsehweig, 1900). 
this advantage over those at University College, satisfactory both to him and to us, that it can be followed by a discussion, and I should like to invite such a discussion upon the clear résumé which has been laid before us of the relations between the north and south of Europe in remote periods.

Mr. MYRES: I an sure that we have all followed with the greatest interest this detailed and masterly exposition of the work which Dr. Montelius has done in this very important subject. Dr. Montelius has given us a full and clear idea of the method of argument by which he has arrived at the conclusion that the successive styles of metal working and other industries as found in North and Central Europe approximately coincide in date with the styles which they most resemble in the Mediterranean area. It has, as we know, been very frequently assumed that a style of metal-working, which is found in the north, belongs to a considerably later epoch to that of a similar object found in the south. But what he said on the question of transit resolves the doubts which some of us have felt as to that. It would probably be possible to collect examples from other parts of the world also, of what seems surprisingly rapid transit from one district to another; one could quote for example the average rate of traflic in Central Africa and Persia, and other instances such as the Himalayan caravan routes, which present far greater difficulties than those which traverse the Alpine barrier. We can well understand, therefore, that although the time allowed for communication may frequently have to be expressed in years, it certainly does not run into centuries.

Another point upon which we should like to have further details, is the extent to wbich Dr. Montelius believes that in the course of a long series, of the kind which he has described, each successive period in the north may be regarded as apparently contemporary with the corresponding period in the south. One can understand that at the end of an interval of 500 or 1000 years the total rate of progress in the north might approximate to the total rate of progress in the south. But we know that in the Mediterranean, for instance, the rate of industrial progress was in all probability not uniform. We have evidence from tine to time, in the Mediterranean, of halts taking place, of complications due to political changes and to emigrations, with the result that for the time some parts of the Mediterranean were apparently plunged back, or at least marked time for a while. Now we should suspect that in a case of that kind corresponding facts would be appreciable in the northern areas; and that at the time of a period of active and progressive commercial development in the Mediterranean, the later style would sometimes outrun the earlier in the northern area. I should like, therefore, to ask Dr. Montelius whether he finds that a period of stagnation in the Mediterranean is represented by a correspondingly long period in the north, and a period of expansion of commerce in the Mediterranean by a succession of short periods. I only mention this point because it might perhaps be of importance to anybody who failed to be convinced by the argument of actual caravan time-tables; and because, before those time-tables had been so clearly presented, some of us here had been inclined to argue that way; my own impression is that very little such overlapping in all probability has taken place, and that we can infer in turn from this that the rate of transit was fairly constant. If it were possible for Dr. Montelius to enlighten us on this point, and to tell us whether he has worked over his material in this way to any extent, the information would be of great interest. 
Professor Montelius: I can say this, that we can always distinguish these two things: objects marle in the south and imported to the north, and things made in the north as imitations of them. We have not the Roman culture in Scandinavia, but we hare something proving a strong influence from that direction. Taking the case of the Benin bronzes as a parallel, we can show that at a certain period there was a connection with Europe, when those peoples made their imitations of European things ; and here, as we can fix the Europen periods, we can say what period that was. I think I ean trace the different periods, in the south, centre, and north of Europe, and I can say for ench period in the north whether it is exactly contemporaneous with each period in the south, because we have so many things made in the south and exported to the north, and we can date them with fair accuracy. It is not impossible to answer Mr. Myres' question, but the details are so voluninous that they could hardly be given now.

I should like to add one remark. I said that an object could make the journey from south to north in anything from lialf a year to two years. But the chief thing to know is what was the outside time that was necessary. We cannot say that everytling was actually carried in so short a time, but if the average time is not one but ten years, it is all the same thing-and the object is contemporary.

Mr. Lewis: I come here quite as a learner in this subject, but as the Chairman has said, Dr. Montelius has entirely ploved his case. I am sorry, however, that he was not able to give us his views on stone tombs. The idea of making a stone tomb to hold a body has occurred to all peoples, and unless some very strong resemblance exists it is not possible to deduce any connection. Now there are considerable differences between the stone tombs of Holland and those of Brittany and this country, and differences exist also between tombs found in different parts of the same country, so I am afraid we cannot say much that is useful about them. I may mention one thing with regard to two tombs, one found in the south of England, and one in the north of Scotland, 800 miles apart. Both of them appear to have been laid down to exactly the same measure, the unit of measurement being the cubit of inches. It is quite obvious from what $D_{2}$ : Montelius says that although the time of transit cannct be fixed to days, months, or even years, yet it is quite another thing to talk about centuries.

The President : In asking you to return thanks to Dr. Montelius I should like to say two or three words, more particularly on the subsidiary lessons which we get from such a statement as he has made this evening. I am inclined to agree with Mr. Lewis that the case is practically proved, and an interesting point is the very short time it took to make what we even now consider by no means a short journey. Many of these points have been before us for a number of years past, but I have never before heard so clear an exposition as Dr. Montelius has given us. I may say I think that Dr. Montelius is in an exceptionally fortunate position, as he belongs to a country where more care is taken of antiquities than in any other zountry of Europe, not so much as regards their exportation, but in such a way that they remain in museums where they can be studied; with the result of producing such lectures as we have heard to-night. As long as we are not very patient of legal restrictions, and think, when we find something, that it will look jetter in our drawing rooms than in any other place, we are not likely to do ustice to our museums. But in course of time, perhaps, we shall improve. One of 
the lessons we can easily learn from Dr. Montelius' lecture is the enormous value of archæology in reproducing for us, in an absolutely accurate form, the history of prehistoric times. In critical literature we are confronted with varying accounts of historians set side by side. The advantage of dealing with prehistoric times is that the evidence is truly set before us by the things themselves, and it depends on our own judgment as to the deductions we make. There are several points which have occurred to me, but as the statutory time has arrived I will not enlarge upon them, except to point out how little effect this commerce had on prehistoric sites in Britain, and on our own art. Looking at these beautiful bronze vessels, ornamented-with bosses and birds, $\mathrm{I}$ cannot help thinking that they are things which might have come to us, but did not. All these trade routes in primitive times had termini, and their object was amber. It is a curious thing that we have so few evidences of continental intercourse with Britain. We had, indeed, some intercourse, but to nothing like the extent that existed between Scandinavia and Central and South-enstern Europe. And this is the more curious because we had here not only tin but gold, as is shown by the discovery here of ornaments which differ from those of the Continent, so that we may assume that the gold itself was found here. It is remarkable, therefore, that there did not exist greater intercourse between the prehistoric peoples of Britain and the Continent.

In asking you to return to Dr. Montelius a vote of thanks, I should like to say how much it has added to our interest and pleasure this evening, that Dr. Montelius has talked to us in our own language, and with as great a facility as we do ourselves. 


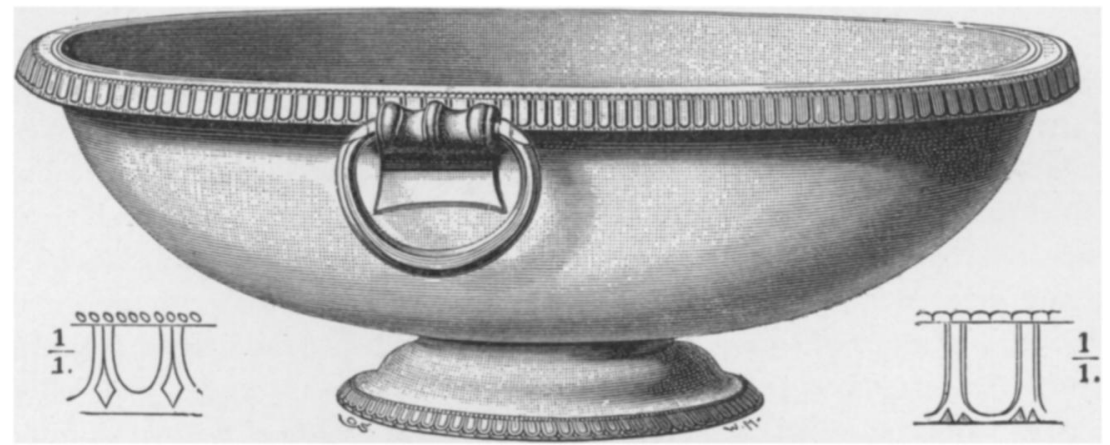

1. Estland. $1 / 4$.

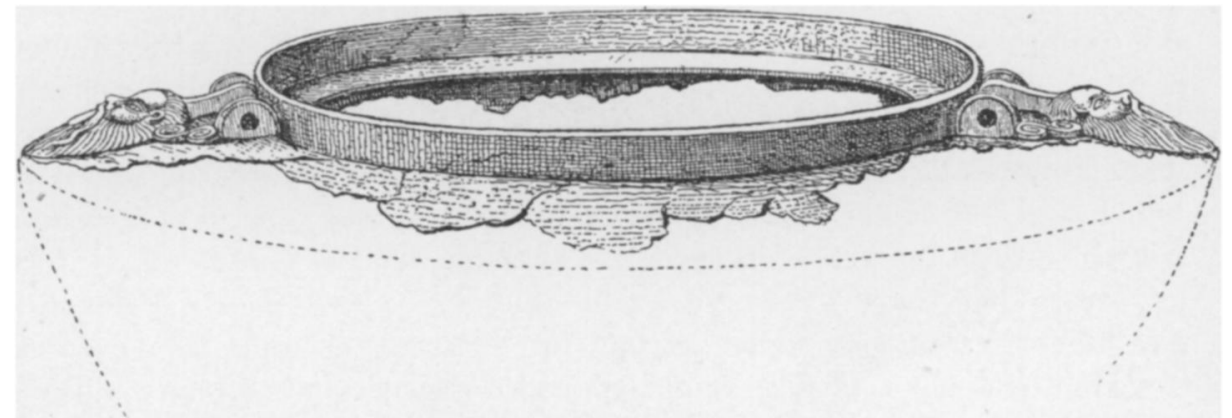

2 a. Denmark. $1 / 4$.

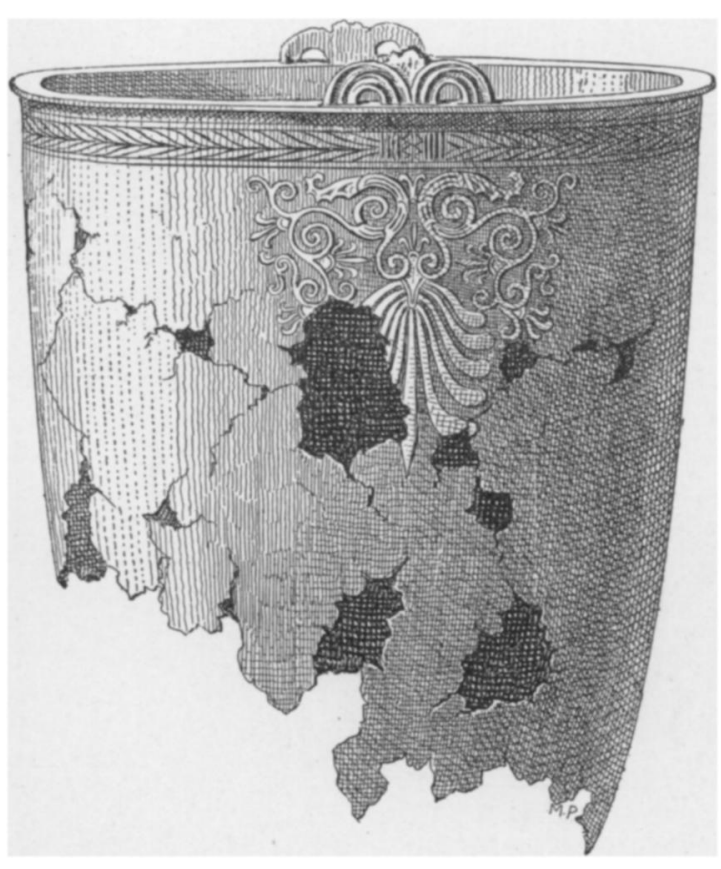

3. Denmark. $1 / 3$.

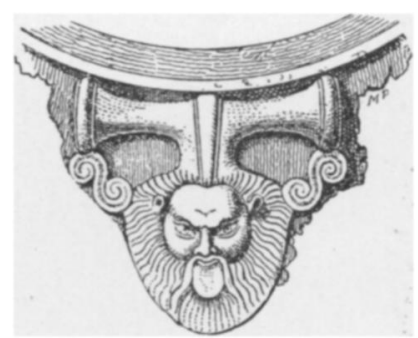

2 b. Detail of fig. 2 a.

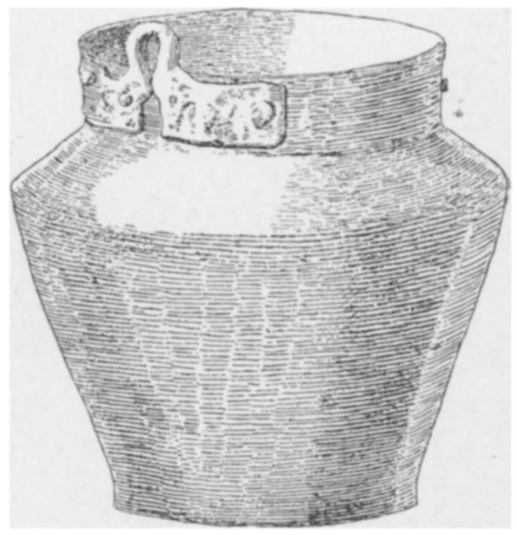

4. Hannover. $1 / 4$. 


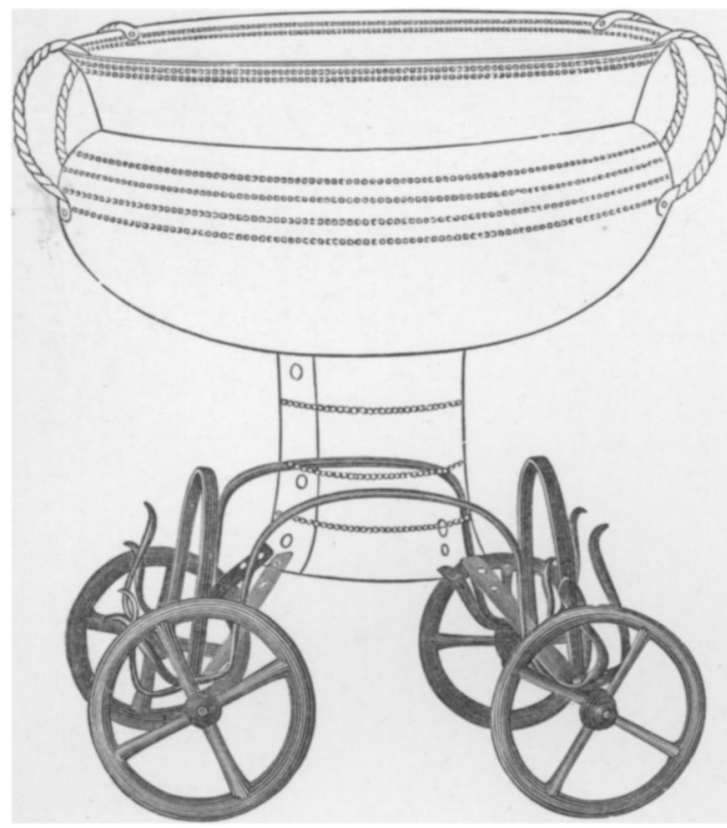

5. SwEden. $1 / 5$.

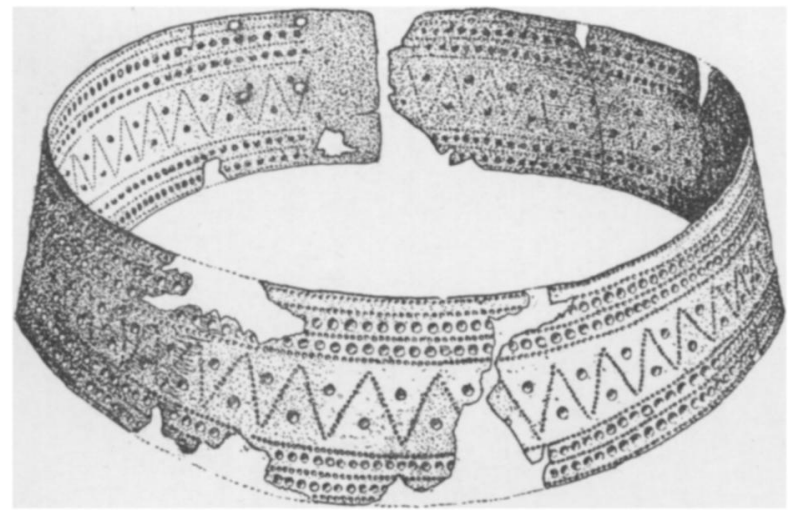

7. Denmark. $1 / 2$.

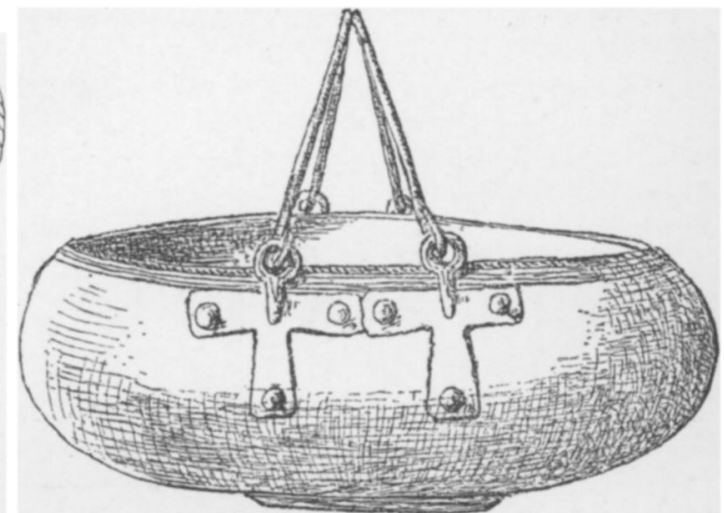

6. Brandenburg. $1 / 4$.

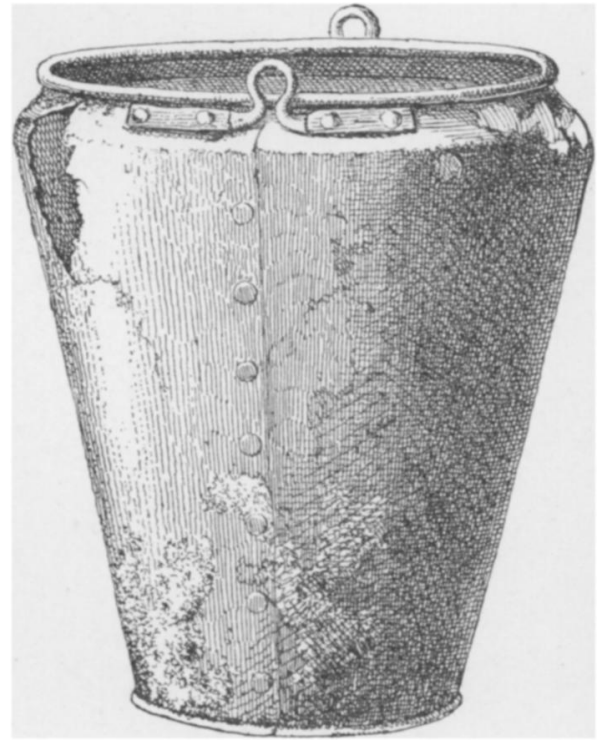

8. Denmark. $1 / 4$.

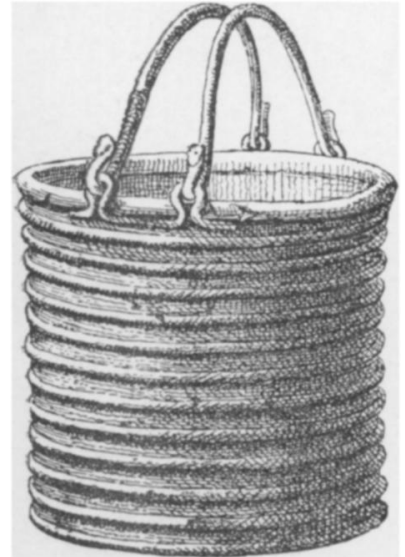

9. Near LüBEck. $1 /$ 7.

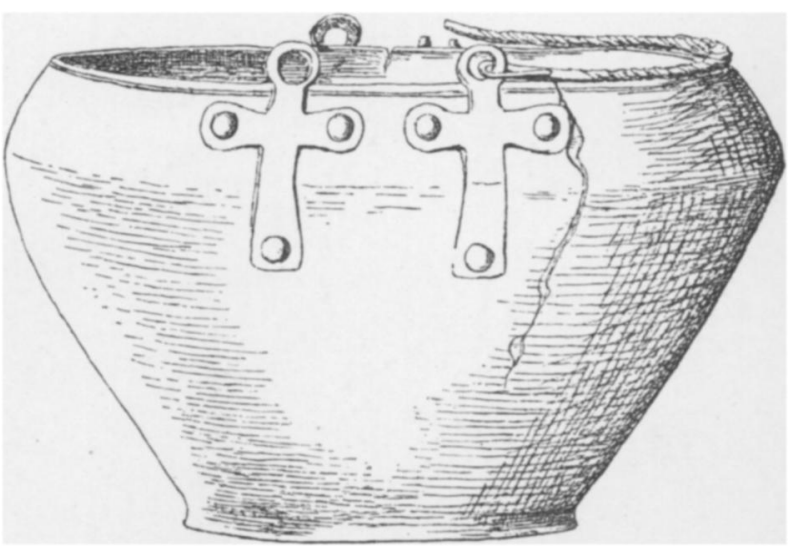

10. Brandenburg. $1 / 4$. 


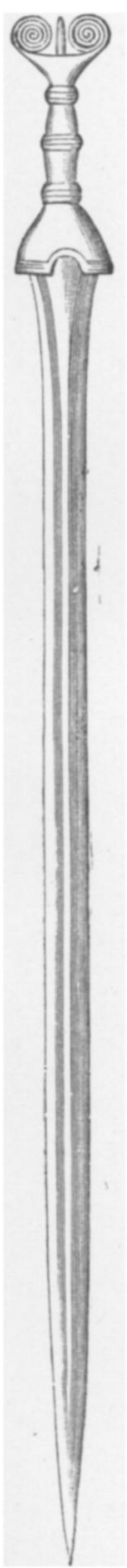

11.

SwEden.

$1 / 5$.

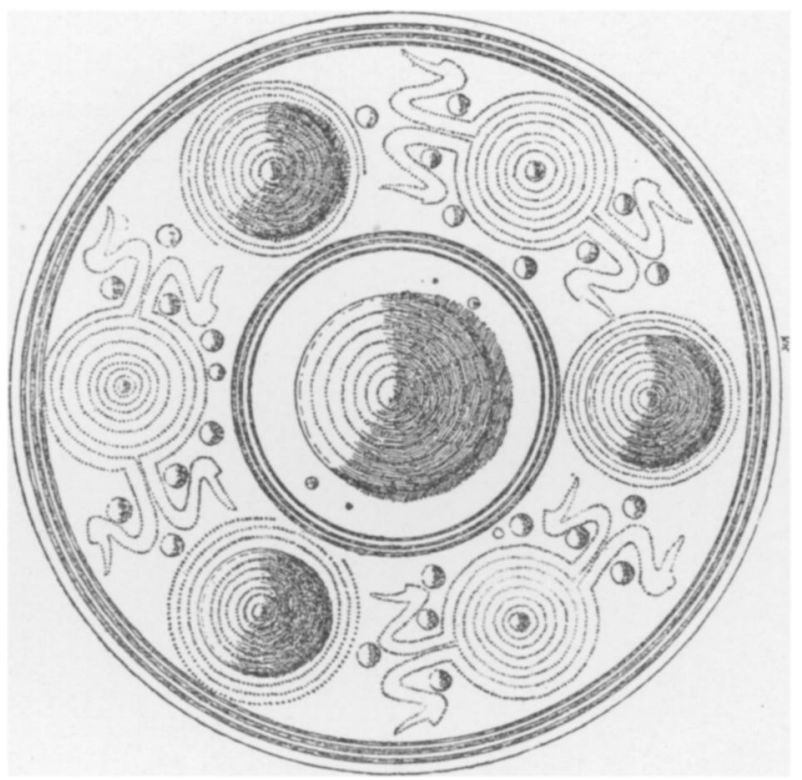

12. Denmark. $1 / 6$.

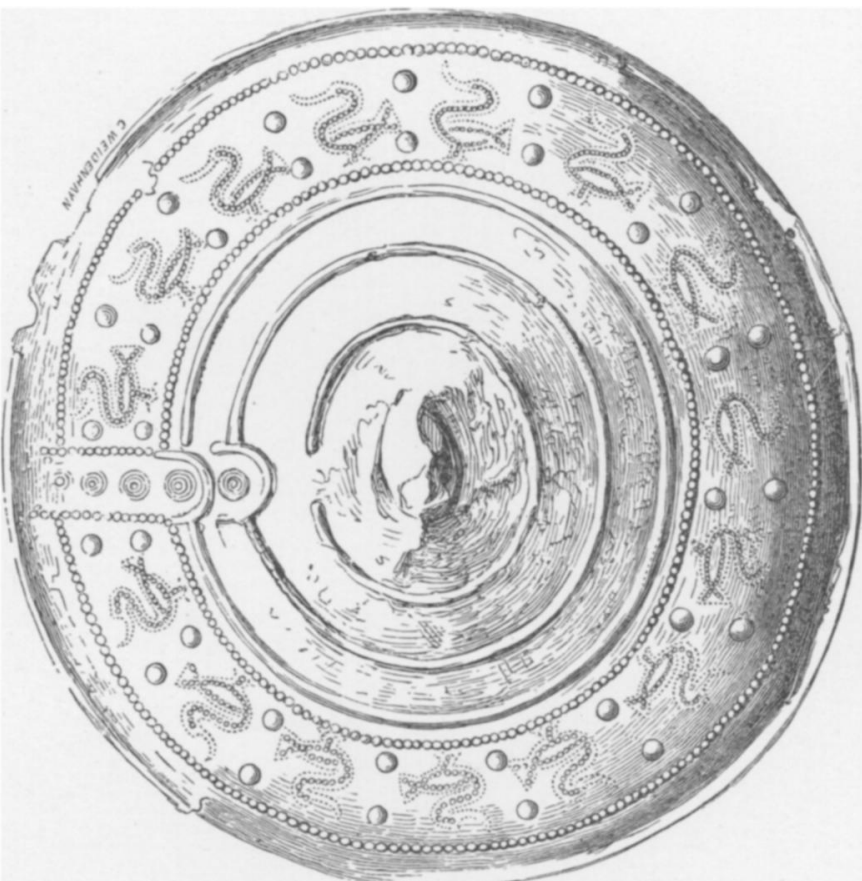

13. SWEDEN. $1 / 8$.

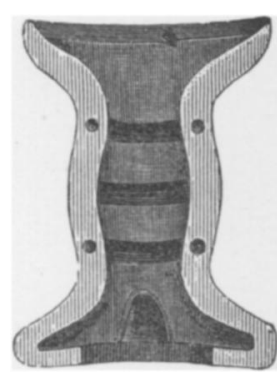

14. Bavaria.

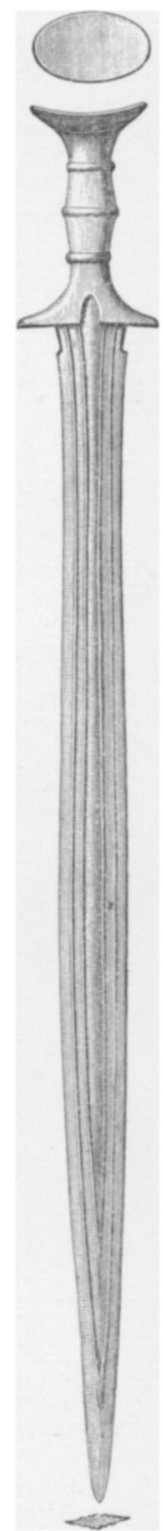

15. Finland. $1 / 5$. 


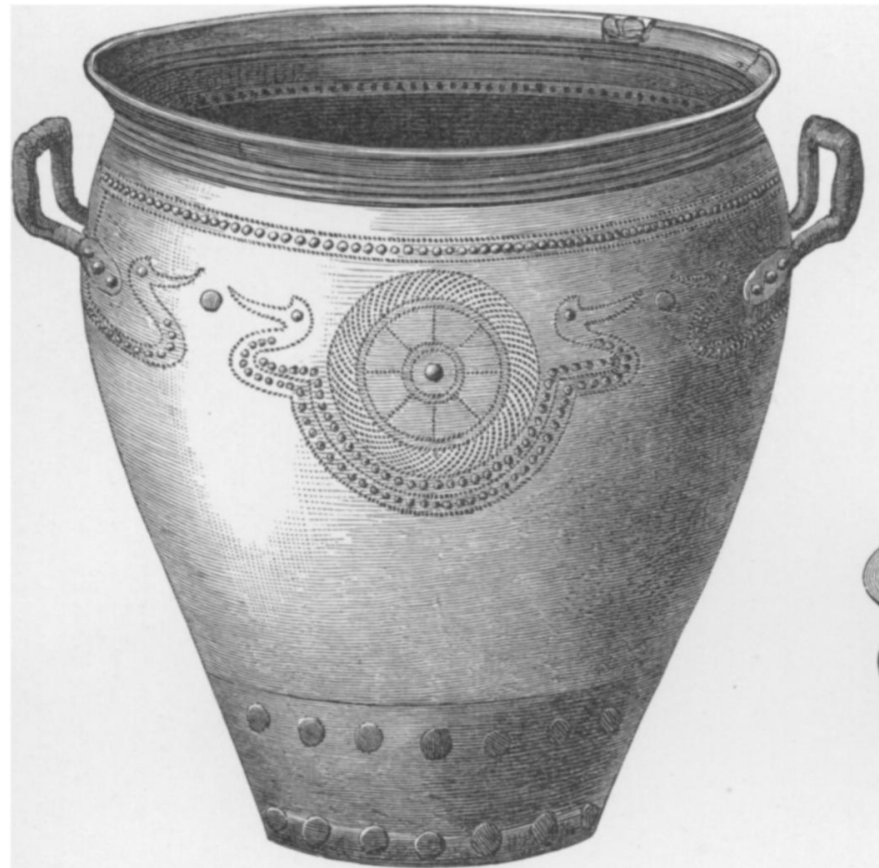

16. Denmark. $1 / 4$.

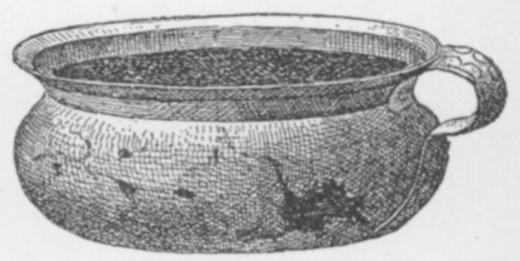

19. Denmark. $1 / 3$.

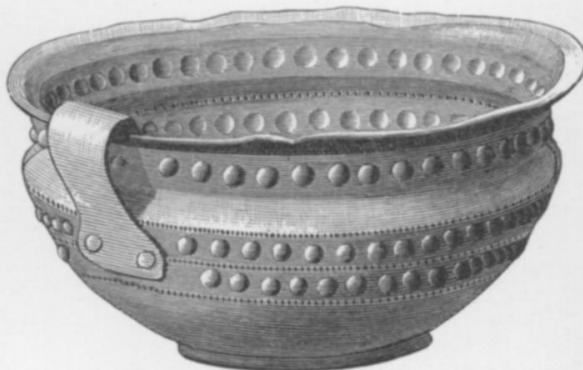

20. Denmark. $1 / 2$.

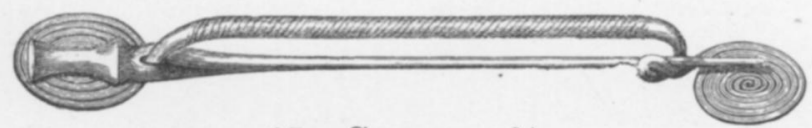

17. Sweden. $2 / 3$.

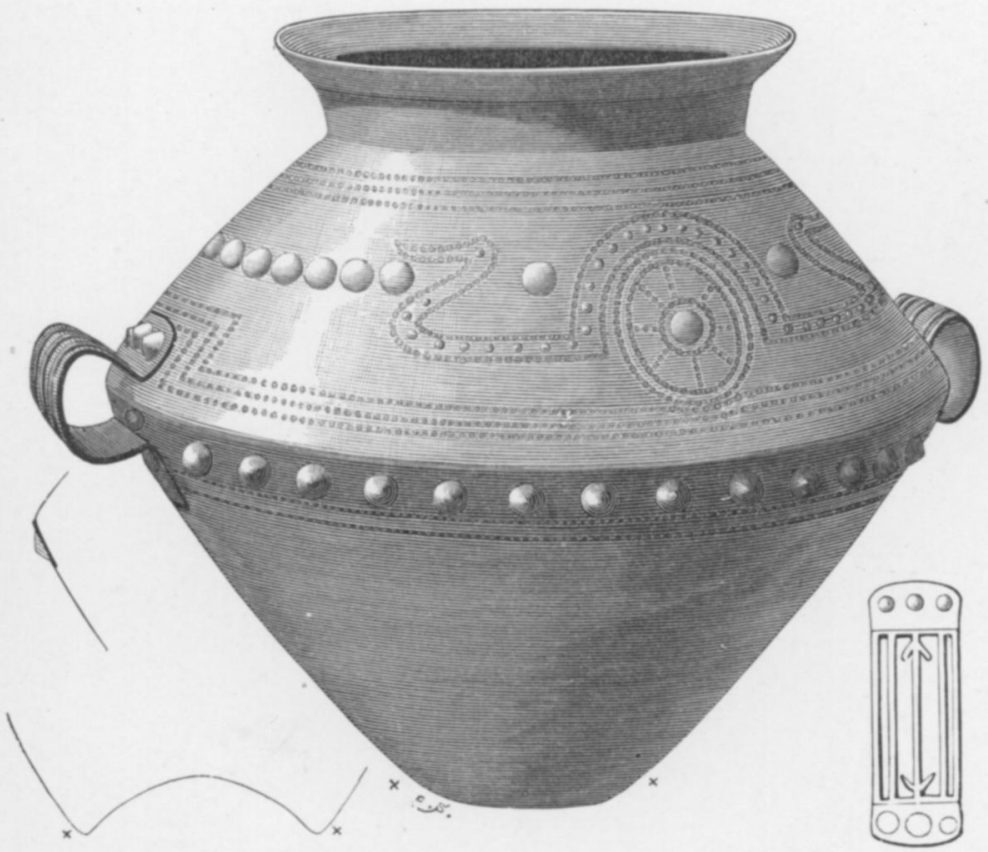

18. Sweden. $1 / 4$.

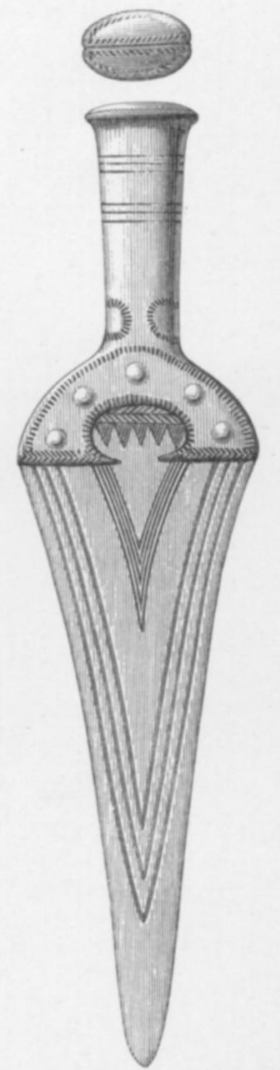

21. Mecklenburg. $1 / 3$. 